\title{
Neural network-based formula for shear capacity prediction of one-way slabs under concentrated loads
}

\author{
Miguel Abambres ${ }^{1}$, Eva Lantsoght ${ }^{2,3 *}$ \\ ${ }^{1}$ R\&D, Abambres’ Lab, 1600-275 Lisbon, Portugal, abambres@netcabo.pt \\ ${ }^{2}$ Politécnico, Universidad San Francisco de Quito, Quito, Ecuador \\ ${ }^{3}$ Concrete Structures, Department of Engineering Structures, Delft University of Technology, Delft, the \\ Netherlands, E.O.L.Lantsoght@tudelft.nl
}

\begin{abstract}
According to the current codes and guidelines, shear assessment of existing reinforced concrete slab bridges sometimes leads to the conclusion that the bridge under consideration has insufficient shear capacity. The calculated shear capacity, however, does not consider the transverse redistribution capacity of slabs, thus leading to overconservative values. This paper proposes an artificial neural network (ANN)-based formula to come up with estimates of the shear capacity of one-way reinforced concrete slabs under a concentrated load, based on 287 test results gathered from the literature. The proposed model yields maximum and mean relative errors of $0.0 \%$ for the 287 data points. Moreover, it was illustrated to clearly outperform (mean $V_{\text {test }}$ $/ V_{A N N}=1.00$ ) the Eurocode 2 provisions (mean $V_{E, E C} / V_{R, c}=1.59$ ) for that dataset. A step-by-step assessment scheme for reinforced concrete slab bridges by means of the ANN-based model is also proposed, which results in an improvement of the current assessment procedures.
\end{abstract}

Keywords: Neural Networks, Design Formula, One-Way Bridge Slabs, Reinforced Concrete, Shear Capacity

Important Note: The first author has been proposing several ANN-based models, in each case designed and tested for a fairly limited amount of data (especially when empirical). Regardless the high quality of the predictions yielded by some model for the used data, the reader should not blindly accept that model as accurate for any other instances falling inside the input domain of the design dataset. Any analytical approximation model must undergo extensive validation before it can be taken as reliable (the more inputs, the larger the validation process). Models proposed until that stage are part of a learning process towards excellence.

Abambres M, Lantsoght E (2018). Neural network-based formula for shear capacity prediction of one-way slabs under concentrated loads, hal-02074675 
D: hal-02074675

(C) 2018 by Abambres M, Lantsoght E (CC BY 4.0)

\section{Introduction}

As the age of existing infrastructures is increasing, the question if existing structures are safe for further operation becomes important. To answer this question, an accurate assessment of the existing infrastructures is necessary. The assessment should not be overly conservative, so that unnecessary strengthening or replacement actions can be avoided. On the other hand, the assessment should be as accurate as possible, so that structural safety can be assured.

When reinforced concrete slab bridges are assessed, the estimated one-way shear capacity can be overly conservative, as transverse redistribution is not considered in the existing codes (Lantsoght et al. 2013a, Lantsoght et al. 2015a). In Europe, the live load model from NEN-EN 1991-2:2003 (CEN 2003) uses a distributed lane load and design tandems. These tandems consist of large concentrated loads that are closely spaced, so that the load combination with the currently prescribed load model in Europe leads to large shear stresses at the support. As a result, a large number of reinforced concrete slab bridges are found to be insufficient for shear when assessed according to the currently governing codes (Walraven 2010).

For more than a century (Talbot 1905, 1906, 1908), researchers have been debating the shear capacity of reinforced concrete members without shear reinforcement (Kani 1964, Regan 1993, Collins and Kuchma 1999). In slabs, the additional dimension of the width makes the problem three-dimensional (Lantsoght et al. 2013b, Lantsoght et al. 2015c). A plasticity-based model 
D: hal-02074675

(C) 2018 by Abambres M, Lantsoght E (CC BY 4.0)

(Lantsoght et al. 2017b, Lantsoght et al. 2017c) has been proposed to estimate the maximum load on a reinforced concrete slab bridge, but this method has the disadvantage that the calculation needs to be tailored to the geometry of the bridge under consideration. Nonlinear finite element models (Falbr 2011) combined with the appropriate safety formats (Schlune 2011, Schlune et al. 2011, Belletti et al. 2013, Blomfors et al. 2016) can be used for the assessment of existing reinforced concrete slab bridges, but this approach is quite time-consuming (Shu et al. 2018).

When a large number of bridges need to be assessed, computationally fast methods are necessary. To determine the sectional shear stresses and bending moments due to the applied load combination, automated procedures using linear finite element models can be used (Frissen 2018). Determining the bending moment capacity can be based on the traditional flexural theory for reinforced concrete beams. For a more effective estimate of the shear capacity of one-way reinforced concrete slabs under a concentrated load, this paper proposes the use of artificial neural networks (ANN), a popular machine learning technique.

Machine learning, one of the six disciplines of Artificial Intelligence (AI) without which the task of having machines acting humanly could not be accomplished, allows us to 'teach' computers how to perform tasks by providing examples of how they should be done (Hertzmann and Fleet 2012). When there is abundant data (also called examples or patterns) explaining a certain phenomenon, but its theory richness is poor, machine learning can be a perfect tool; as such its application to the problem 
D: hal-02074675

(C) 2018 by Abambres M, Lantsoght E (CC BY 4.0)

of shear in one-way slabs is suitable and timely. The Artificial Neural Network (also referred in this manuscript as ANN or neural net) is the (i) oldest (McCulloch and Pitts 1943) and (ii) most powerful (Hern 2016) technique of machine learning. ANNs also lead the number of practical applications, virtually covering any field of knowledge (Wilamowski and Irwin 2011, Prieto et al. 2016). In its most general form, an ANN is a mathematical model designed to perform a particular task, based in the way the human brain processes information, i.e. with the help of its processing units (the neurons). ANNs have been employed to perform several types of real-world basic tasks, and have been successfully applied to civil engineering problems (Flood and Kartam 1994, Mukherjee et al. 1996, Aymerich and Serra 1998, Pu and Mesbahi 2006, Gholizadeh et al. 2011, Naser 2018, Venkata Rao and Murthy 2018, Weinstein Jordan et al. 2018, Yaseen et al. 2018). Some efforts have also been geared towards using ANN-based prediction models for the problem related to shear in structural concrete, yet these models still have relatively large errors (Adhikary and Mutsuyoshi 2006, Jung and Kim 2008, Gandomi et al. 2013, Kara 2013, Naik and Kute 2013, Sarveghadi et al. 2015, Hossain et al. 2016, Al-Musawi 2018).

Tab. 1. Variables adopted in the study, showing minimum and maximum values in the database. 
ID: hal-02074675

C) 2018 by Abambres M, Lantsoght E (CC BY 4.0)

\begin{tabular}{|c|c|c|c|c|c|}
\hline \multicolumn{3}{|c|}{ Input Variables } & $\min$ & $\max$ & Input \\
\hline \multirow{4}{*}{$\begin{array}{c}\text { Slab } \\
\text { geometry }\end{array}$} & $\boldsymbol{b}(\mathrm{m})$ & slab width & 0.249 & 11.125 & 1 \\
\hline & $\boldsymbol{h}(\mathrm{m})$ & slab height & 0.100 & 1.005 & 2 \\
\hline & $\boldsymbol{d}_{l}(\mathrm{~m})$ & slab effective depth & 0.080 & 0.916 & 6 \\
\hline & Ispan $(\mathrm{m})$ & span length & 0.600 & 12.192 & 9 \\
\hline Material & $\boldsymbol{f}_{c m}(\mathrm{MPa})$ & average concrete cylinder compressive strength & 12.4 & 77.7 & 3 \\
\hline \multirow{2}{*}{ Reinforcement } & $\boldsymbol{\rho}_{\boldsymbol{x}}(-)$ & longitudinal reinforcement ratio & 0.003 & 0.028 & 4 \\
\hline & $\boldsymbol{\rho}_{y}(-)$ & transverse reinforcement ratio & 0 & 0.015 & 5 \\
\hline \multirow{4}{*}{ Loading parameters } & $\boldsymbol{b}_{\boldsymbol{r}}(\mathrm{m})$ & distance from slab edge to the center of the load & 0.125 & 5.563 & 7 \\
\hline & lload $(\mathrm{m})$ & dimension of the loading plate (wheel print) & 0.070 & 2.519 & 8 \\
\hline & $M_{E} / V_{E} d_{I}(-)$ & $\begin{array}{l}\text { ratio of sectional moment to } \\
\text { product of sectional shear and effective depth }\end{array}$ & 0.14 & 10.75 & 10 \\
\hline & $a_{v} / d_{l}(-)$ & ratio of clear shear span to effective depth & 0.00 & 6.88 & 11 \\
\hline \multicolumn{3}{|c|}{ Output Variables } & & & Output \\
\hline \multicolumn{2}{|l|}{$V_{\boldsymbol{R}}(\mathrm{kN})$} & shear capacity & 35 & 2444 & 1 \\
\hline
\end{tabular}

Concerning functional approximation, ANN-based solutions are frequently more accurate than those provided by traditional approaches, such as multi-variate nonlinear regression, besides not requiring a good knowledge of the function shape being modelled (Flood 2008). The proposed ANN was designed based on the 287 experimental results available to date in the literature. The goal of this study is not to provide a full description of the mechanics underlying the behaviour of one-way reinforced concrete slabs.

\section{Data Gathering}

The dataset used for the development of the ANN simulations consists of 287 experimental results from (i) tests gathered from the literature reported in (Lantsoght et al. 2015b), namely Graf 1933, Richart and Kluge 1939, Richart 1948a, b, Diaz de Cossio et al. 1962, Leonhardt and Walther 1962a, b, 
D: hal-02074675

(C) 2018 by Abambres M, Lantsoght E (CC BY 4.0)

Rajagopalan and Ferguson 1968, Aster and Koch 1974, Reineck et al. 1978, Kani et al. 1979, Heger and McGrath 1980, Ekeberg et al. 1982, Regan 1982, Regan and Rezai-Jorabi 1988, Fang et al. 1990, Miller et al. 1994, Cullington et al. 1996, Furuuchi et al. 1998, Olonisakin and Alexander 1999, Serna-Ros et al. 2002, Jäger 2005, Rombach and Velasco 2005, Sherwood et al. 2006, Vaz Rodrigues 2006, Vaz Rodrigues et al. 2006, Coin and Thonier 2007, Jäger 2007, Rombach and Latte 2008, Jaeger and Marti 2009, Rombach et al. 2009, Reißen and Hegger 2011, 2013a, b, (ii) the TU Delft slab shear tests (Lantsoght 2013), and (iii) recently reported experiments (Mohammadyan-Yasouj et al. 2015). Eleven variables were adopted as input (independent) for the ANN-based shear capacity predictions, as described and illustrated in Tab. 1 and Fig. 1, respectively. Note that the proposed ANN features just 10 nodes in the first layer, which inputs have to be obtained as function of those eleven variables, as described in \$3.7.1. For all experiments, the sectional shear and moment were calculated considering all loads, thus including the self-weight. For the case of a continuous slab shown in Fig. 1, the slight gradient in the shear diagram and the slight nonlinearity in the bending moment diagram are caused by the self-weight. All values of the concrete compressive strength are the cylinder compressive strength. This value was either reported in the original reference, or calculated as $82 \%$ of the cube compressive strength (van der Veen and Gijsbers 2011). The corresponding 287-point dataset is publicly available (Developer 2018a), and was constructed by randomly ordering the collected experimental results.

\section{Artificial Neural Networks}


D: hal-02074675

(C) 2018 by Abambres M, Lantsoght E (CC BY 4.0)

\subsection{Introduction}

The general ANN structure consists of several nodes in $L$ vertical layers (input layer, hidden layers, and output layer) and connected between them, as depicted in Fig. 2. Associated to each node in layers 2 to $L$, also called neuron, is a linear or nonlinear transfer (also called activation) function, which receives the so-called net input and transmits an output. All ANNs implemented in this work are called feedforward, since data presented in the input layer flows in the forward direction only, i.e. every node only connects to nodes belonging to layers located at the right-handside of its layer, as shown in Fig. 2. ANN's computing power makes them suitable to efficiently solve small to large-scale complex problems, which can be attributed to their (i) massively parallel distributed structure and (ii) ability to learn and generalize, i.e, produce reasonably accurate outputs for inputs not used during the learning (also called training) phase. 
: hal-02074675

(C) 2018 by Abambres M, Lantsoght E (CC BY 4.0)

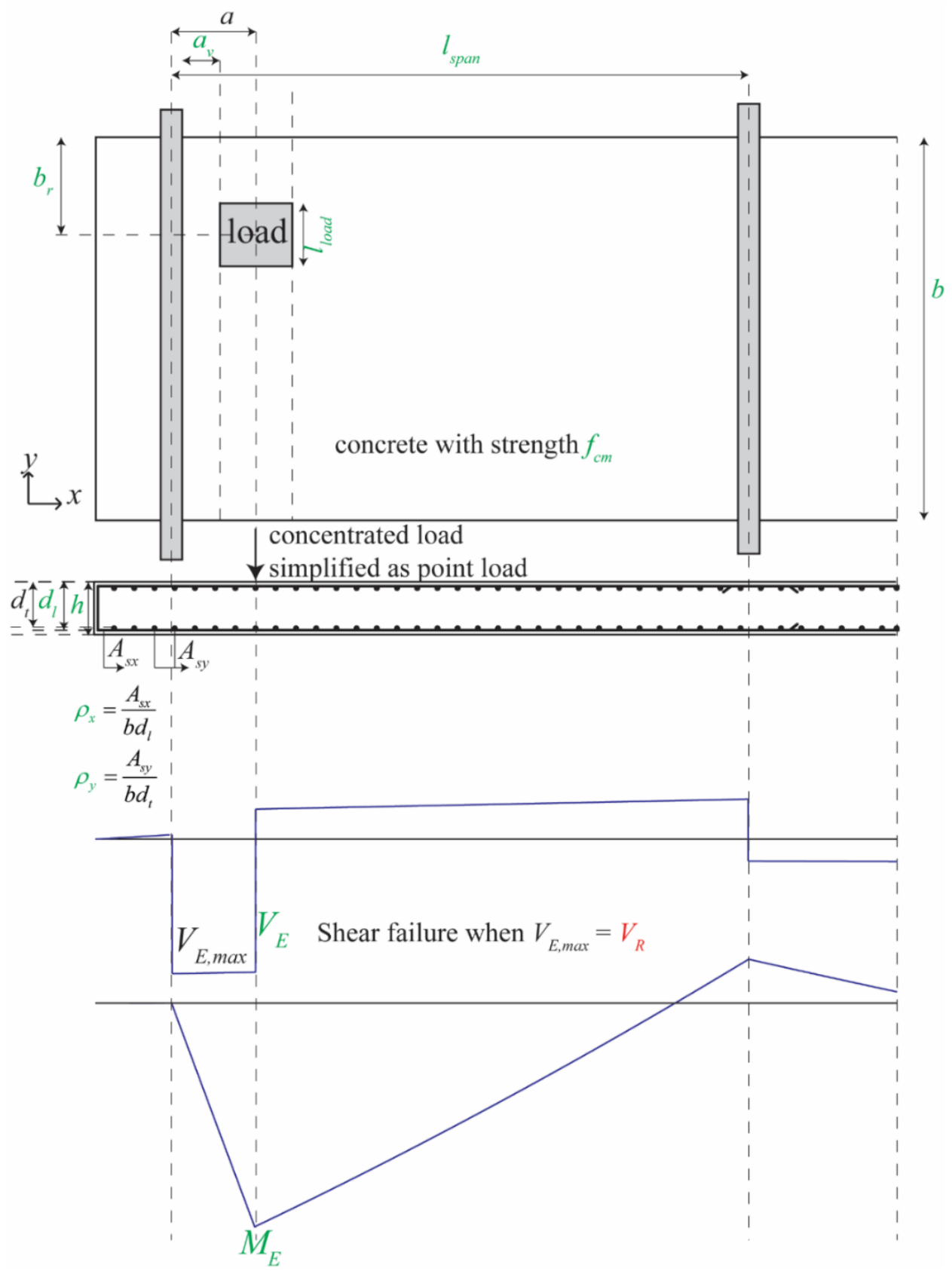

Fig. 1. Input (independent) and output (dependent) variables considered in ANN design.

Abambres M, Lantsoght E (2018). Neural network-based formula for shear capacity prediction of one-way slabs under concentrated loads, hal-02074675 
: hal-02074675

(C) 2018 by Abambres M, Lantsoght E (CC BY 4.0)

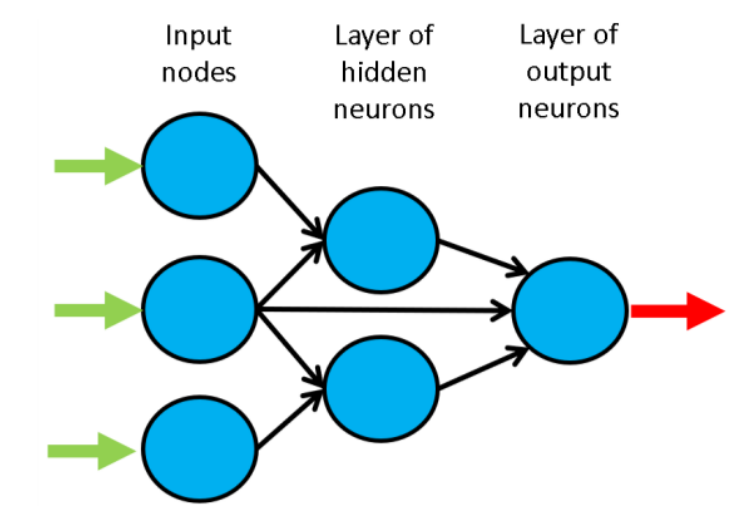

Fig. 2. Example of a feedforward neural network.

\subsection{Learning}

Each connection between 2 nodes is associated to a synaptic weight (real value), which, together with each neuron's bias (also a real value), are the most common types of neural net unknown parameters that will be determined through learning. Learning is nothing else than determining network unknown parameters through some algorithm in order to minimize the network's performance measure, typically a function of the difference between predicted and target (desired) outputs. When ANN learning has an iterative nature, it consists of three phases: (i) training, (ii) validation, and (iii) testing. From previous knowledge, examples or data points are selected to train the neural net, grouped in the so-called training dataset. Those examples are said to be 'labeled' or 'unlabeled', whether they consist of inputs paired with their targets, or just of the inputs themselves

- learning is called supervised (e.g., functional approximation, classification) or unsupervised 
D: hal-02074675

(C) 2018 by Abambres M, Lantsoght E (CC BY 4.0)

(e.g., clustering), whether data used is labelled or unlabeled, respectively. During an iterative learning, while the training dataset is used to tune network unknowns, a process of cross-validation takes place by using a set of data completely distinct from the training counterpart (the validation dataset), so that the generalization performance of the network can be attested. Once 'optimum' network parameters are determined, typically associated to a minimum of the validation performance curve (called early stop - see Fig. 3), many authors still perform a final assessment of model's accuracy, by presenting to it a third fully distinct dataset called 'testing'. Heuristics suggests that early stopping avoids overfitting, i.e. the loss of ANN's generalization ability. One of the causes of overfitting might be learning too many input-target examples suffering from data noise, since the network might learn some of its features, which do not belong to the underlying function being modelled (Haykin 2009).

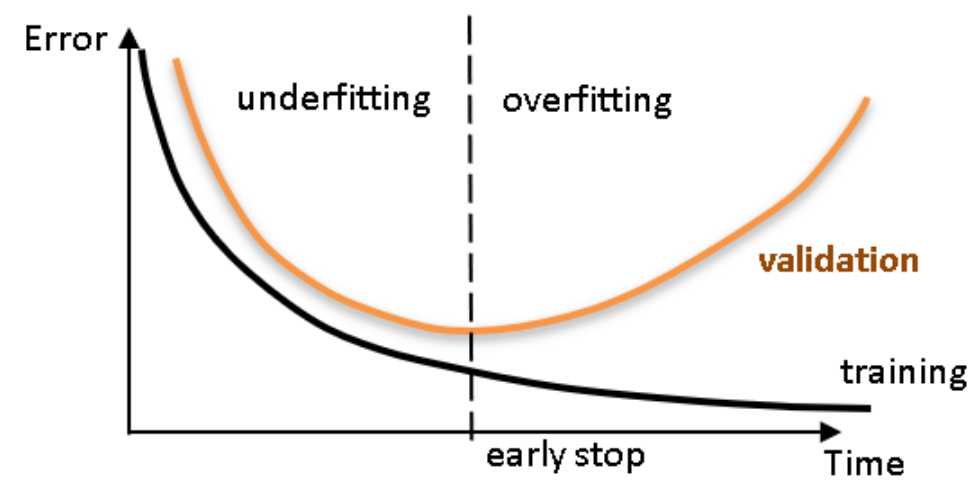

Fig. 3. Cross-validation - assessing network's generalization ability. 
D: hal-02074675

(C) 2018 by Abambres M, Lantsoght E (CC BY 4.0)

\subsection{Implemented ANN features}

The 'behavior' of any ANN depends on many 'features', with 15 ANN features implemented in this work (including data pre/post processing ones). For those features, it is important to bear in mind that no ANN guarantees good approximations via extrapolation (either in functional approximation or classification problems), i.e. the implemented ANNs should not be applied outside the input variable ranges used for network training. Since there are no objective rules dictating which method per feature guarantees the best network performance for a specific problem, an extensive parametric analysis (composed of nine parametric sub-analyses) was carried out to find 'the optimum' net design. A description of all methods/formulations implemented for each ANN feature (see Tabs. 2-4; these are a selection from the state-of-the-art on ANNs, including both traditional and promising modern techniques), can be found in previous published works (e.g., Abambres et al. 2018); the interested reader is referred to these works if he/she wants to deeply understand or reproduce the work shown in this paper. The code was developed in MATLAB (The Mathworks 2017), making use of its neural network toolbox when dealing with popular learning algorithms (1-3 from F13 in Tab. 4). Each parametric sub-analysis (SA) consists of running all feasible combinations (also called 'combos') of pre-selected methods for each ANN feature, in order to get performance results for each designed net, thus allowing the selection of the best ANN 
D: hal-02074675

(C) 2018 by Abambres M, Lantsoght E (CC BY 4.0)

according to a certain criterion. The best network in each parametric SA is the one exhibiting the smallest average relative error (called performance) for all learning data.

Tab. 2. Implemented ANN features (F) 1-5.

\begin{tabular}{cccccc}
\hline \multirow{2}{*}{$\begin{array}{c}\text { FEATURE } \\
\text { METHOD }\end{array}$} & F1 & F2 & F3 & F4 & F5 \\
\cline { 2 - 7 } & $\begin{array}{c}\text { Qualitative } \\
\text { Var Represent }\end{array}$ & $\begin{array}{c}\text { Dimensional } \\
\text { Analysis }\end{array}$ & $\begin{array}{c}\text { Input Dimensionality } \\
\text { Reduction }\end{array}$ & $\begin{array}{c}\text { Train-Valid- } \\
\text { Test }\end{array}$ & $\begin{array}{c}\text { Input } \\
\text { Normalization }\end{array}$ \\
\hline $\mathbf{1}$ & Boolean Vectors & Yes & Linear Correlation & $80-10-10$ & Linear Max Abs \\
$\mathbf{2}$ & Eq Spaced in & No & Auto-Encoder & $70-15-15$ & Linear $[0,1]$ \\
$\mathbf{3}$ & j0,1] & - & - & $60-20-20$ & Linear $[-1,1]$ \\
$\mathbf{4}$ & - & - & Ortho Rand Proj & $50-25-25$ & Nonlinear \\
$\mathbf{5}$ & - & - & Sparse Rand Proj & - & Lin Mean Std \\
$\mathbf{6}$ & - & - & No & - & No \\
\hline
\end{tabular}

Tab. 3. Implemented ANN features (F) 6-10.

\begin{tabular}{|c|c|c|c|c|c|}
\hline \multirow[b]{2}{*}{$\begin{array}{l}\text { FEATURE } \\
\text { METHOD }\end{array}$} & F6 & F7 & F8 & F9 & F10 \\
\hline & $\begin{array}{l}\text { Output } \\
\text { Transfer }\end{array}$ & $\begin{array}{c}\text { Output } \\
\text { Normalization }\end{array}$ & $\begin{array}{c}\text { Net } \\
\text { Architecture }\end{array}$ & $\begin{array}{l}\text { Hidden } \\
\text { Layers }\end{array}$ & Connectivity \\
\hline $\begin{array}{l}1 \\
2\end{array}$ & Logistic & $\begin{array}{l}\operatorname{Lin}[a, b]=0.7\left[\varphi_{\min }, \varphi_{\max }\right] \\
\operatorname{Lin}[a, b]=0.6\left[\varphi_{\min }, \varphi_{\max }\right]\end{array}$ & $\begin{array}{l}\text { MLPN } \\
\text { RBFN }\end{array}$ & $\begin{array}{l}1 \mathrm{HL} \\
2 \mathrm{HL}\end{array}$ & $\begin{array}{l}\text { Adjacent Layers } \\
\text { Adj Layers + In-Out }\end{array}$ \\
\hline 3 & Hyperbolic Tang & $\operatorname{Lin}[a, b]=0.5\left[\varphi_{\min }, \varphi_{\max }\right]$ & - & $3 \mathrm{HL}$ & Fully-Connected \\
\hline 4 & - & Linear Mean Std & - & - & - \\
\hline 5 & Bilinear & No & - & - & - \\
\hline 6 & Compet & - & - & - & - \\
\hline 7 & Identity & - & - & - & - \\
\hline
\end{tabular}


ID: hal-02074675

C) 2018 by Abambres M, Lantsoght E (CC BY 4.0)

Tab. 4. Implemented ANN features (F) 11-15.

\begin{tabular}{|c|c|c|c|c|c|}
\hline FFATIRF & F11 & F12 & F13 & F14 & F15 \\
\hline METHOD & $\begin{array}{l}\text { Hidden } \\
\text { Transfer }\end{array}$ & $\begin{array}{c}\text { Parameter } \\
\text { Initialization }\end{array}$ & $\begin{array}{l}\text { Learning } \\
\text { Algorithm }\end{array}$ & $\begin{array}{l}\text { Performance } \\
\text { Improvement }\end{array}$ & $\begin{array}{l}\text { Training } \\
\text { Mode }\end{array}$ \\
\hline 1 & Logistic & Midpoint (W) + Rands (b) & $\mathrm{BP}$ & NNC & Batch \\
\hline 2 & Identity-Logistic & Rands & BPA & - & Mini-Batch \\
\hline 3 & Hyperbolic Tang & Randnc (W) + Rands (b) & LM & - & Online \\
\hline 4 & Bipolar & Randnr (W) + Rands (b) & ELM & - & - \\
\hline 5 & Bilinear & Randsmall & $\mathrm{mb}$ ELM & - & - \\
\hline 6 & Positive Sat Linear & Rand $[-\Delta, \Delta]$ & I-ELM & - & - \\
\hline 7 & Sinusoid & SVD & Cl-ELM & - & - \\
\hline 8 & Thin-Plate Spline & MB SVD & - & - & - \\
\hline 9 & Gaussian & - & - & - & - \\
\hline 10 & Multiquadratic & ـ & - & - & - \\
\hline 11 & Radbas & - & - & - & - \\
\hline
\end{tabular}

\subsection{Network Performance Assessment}

Several types of results were computed to assess network outputs, namely (i) maximum error, (ii) $\%$ errors greater than $3 \%$, and (iii) performance, which are defined next. All abovementioned errors are relative errors (expressed in \%) based on the following definition, concerning a single output variable (as is the case for the studied problem) and data pattern,

$$
e_{q p}=100\left|\frac{d_{q p}-y_{q L p}}{d_{q p}}\right|
$$

where (i) $d_{q p}$ is the $q^{\text {th }}$ desired (or target) output when pattern $p$ within iteration $i\left(p=1, \ldots, P_{i}\right)$ is presented to the network, and (ii) $y_{q L p}$ is net's $q^{\text {th }}$ output for the same data pattern. Moreover, the denominator in eq. (1) is replaced by 1 whenever $\left|d_{q p}\right|<0.05 ; d_{q p}$ in the nominator keeps its real value. This exception to eq. (1) aims to reduce the apparent negative effect of large relative errors associated to target values close to zero. Even so, this trick may still lead to (relatively) large 
D: hal-02074675

(C) 2018 by Abambres M, Lantsoght E (CC BY 4.0)

solution errors when groundbreaking results are depicted as regression plots (target vs. predicted outputs).

\subsubsection{Maximum Error}

This variable measures the maximum relative error, as defined by eq. (1), among all output variables and learning patterns.

\subsubsection{Percentage of Errors > 3\%}

This variable measures the percentage of relative errors, as defined by eq. (1), among all output variables and learning patterns that are greater than $3 \%$.

\subsubsection{Performance}

In functional approximation problems, network performance is defined as the average relative error, as defined in eq. (1), among all output variables and data patterns being evaluated (e.g., training, all data).

\subsection{Software Validation}

Several benchmark datasets/functions were used to validate the developed software, involving low- to high-dimensional problems and small to large volumes of data. The interested reader can find the results of the validation online (Researcher 2018). 
D: hal-02074675

(C) 2018 by Abambres M, Lantsoght E (CC BY 4.0)

\subsection{Parametric Analysis Results}

Aiming to reduce the computational time by reducing the number of combos to be ran (note that all features combined lead to hundreds of millions of combos), the whole parametric simulation was divided into nine parametric SAs, where in each one feature 7 only takes a single value. This measure aims to make the performance ranking of all combos within each 'small' analysis more 'reliable', since results used for comparison are based on target and output datasets as used in ANN training and yielded by the designed network, respectively (they are free of any post-processing that eliminates output normalization effects on relative error values). Whereas (i) the $1^{\text {st }}$ and $2^{\text {nd }} \mathrm{SAs}$ aimed to select the best methods from features 1, 2, 5, 8 and 13 (all combined), while adopting a single popular method for each of the remaining features $\left(F_{3}: 6, F_{4}: 2, F_{6}:\{1\right.$ or 7\}, F $F_{7}: 1, F_{9}: 1, F_{10}: 1, F_{11}:\left\{3,9\right.$ or 11\}, F $F_{12}: 2, F_{14}: 1, F_{15}: 1$ - see Tabs. 2-4) - SA 1 involved learning algorithms 1-3 and SA 2 involved the ELM-based counterpart, (ii) the $3^{\text {rd }}-7^{\text {th }}$ SAs combined all possible methods from features 3, 4, 6 and 7, and concerning all other features, adopted the methods integrating the best combination from the aforementioned first SA, (iii) the $8^{\text {th }}$ SA combined all possible methods from features 11,12 and 14 , and concerning all other features, adopted the methods integrating the best combination (results compared after postprocessing) among the previous five sub-analyses, and lastly (iv) the $9^{\text {th }}$ SA combined all possible methods from features 9,10 and 15 , and concerning all other features, adopted the methods 
D: hal-02074675

(C) 2018 by Abambres M, Lantsoght E (CC BY 4.0)

integrating the best combination from the previous analysis. Summing up the ANN feature combinations for all parametric SAs, a total of 475 combos were ran for this work.

The ANN feature methods used in the best combo from each of the abovementioned nine parametric sub-analyses are specified in Tab. 5 (the numbers represent the method number as in Tabs 2-4). Tab. 6 shows the corresponding relevant results for those combos, namely (i) maximum error, (ii) \% errors $>3 \%$, (iii) performance (see $\$ 3.4$ - evaluated for all learning data), (iv) total number of hidden nodes in the model, and (v) average computing time per example (including data pre- and post-processing). All results shown in Tab. 6 are based on target and output datasets computed in their original format, i.e. free of any transformations due to output normalization and/or dimensional analysis. The microprocessors used in this work have the following features: OS: Win10Home 64bits, RAMs: 128 GB, Local Disk Memory: 1 TB, CPUs: Intel ${ }^{\circledR}$ Core $^{\mathrm{TM}}$ i9 7960X@2.80-4.20 GHz.

Tab. 5. ANN feature (F) methods used in the best combo from each parametric sub-analysis (SA).

\begin{tabular}{cccccccccccccccc}
\hline SA & F1 & F2 & F3 & F4 & F5 & F6 & F7 & F8 & F9 & F10 & F11 & F12 & F13 & F14 & F15 \\
\hline $\mathbf{1}$ & 1 & 2 & 6 & 2 & 5 & 1 & 1 & 1 & 1 & 1 & 3 & 2 & 3 & 1 & 3 \\
$\mathbf{2}$ & 1 & 2 & 6 & 2 & 1 & 7 & 1 & 1 & 1 & 1 & 3 & 2 & 5 & 1 & 3 \\
$\mathbf{3}$ & 1 & 2 & 1 & 3 & 5 & 1 & 1 & 1 & 1 & 1 & 3 & 2 & 3 & 1 & 3 \\
$\mathbf{4}$ & 1 & 2 & 1 & 3 & 5 & 1 & 2 & 1 & 1 & 1 & 3 & 2 & 3 & 1 & 3 \\
$\mathbf{5}$ & 1 & 2 & 1 & 4 & 5 & 1 & 3 & 1 & 1 & 1 & 3 & 2 & 3 & 1 & 3 \\
$\mathbf{6}$ & 1 & 2 & 1 & 4 & 5 & 7 & 4 & 1 & 1 & 1 & 3 & 2 & 3 & 1 & 3 \\
$\mathbf{7}$ & 1 & 2 & 1 & 1 & 5 & 7 & 5 & 1 & 1 & 1 & 3 & 2 & 3 & 1 & 3 \\
$\mathbf{8}$ & 1 & 2 & 1 & 1 & 5 & 7 & 5 & 1 & 1 & 1 & 5 & 5 & 3 & 1 & 3 \\
$\mathbf{9}$ & 1 & 2 & 1 & 1 & 5 & 7 & 5 & 1 & 2 & 3 & 5 & 5 & 3 & 1 & 3 \\
\hline
\end{tabular}

Abambres M, Lantsoght E (2018). Neural network-based formula for shear capacity prediction of 
ID: hal-02074675

(C) 2018 by Abambres M, Lantsoght E (CC BY 4.0)

Tab. 6. Performance results for the best design from each parametric sub-analysis: (a) ANN, (b) NNC.

\begin{tabular}{|c|c|c|c|c|c|}
\hline \multirow[b]{2}{*}{ SA } & \multicolumn{5}{|c|}{ ANN } \\
\hline & $\begin{array}{c}\text { Max Error } \\
(\%)\end{array}$ & $\begin{array}{c}\text { Performance } \\
\text { All Data } \\
(\%)\end{array}$ & $\begin{array}{c}\text { Errors > } 3 \% \\
(\%)\end{array}$ & $\begin{array}{l}\text { Total Hidden } \\
\text { Nodes }\end{array}$ & $\begin{array}{c}\text { Running Time / } \\
\text { Data Point } \\
\text { (s) }\end{array}$ \\
\hline 1 & 0.0 & 0.0 & 0.0 & 44 & $2.13 \mathrm{E}-04$ \\
\hline 2 & 559.9 & 34.0 & 88.2 & 70 & $1.46 \mathrm{E}-04$ \\
\hline 3 & 0.0 & 0.0 & 0.0 & 37 & $2.43 E-04$ \\
\hline 4 & 0.0 & 0.0 & 0.0 & 37 & $3.38 \mathrm{E}-04$ \\
\hline 5 & 0.0 & 0.0 & 0.0 & 37 & $1.77 \mathrm{E}-04$ \\
\hline 6 & 0.0 & 0.0 & 0.0 & 40 & $2.22 \mathrm{E}-04$ \\
\hline 7 & 171.0 & 5.8 & 30.3 & 29 & $1.48 \mathrm{E}-04$ \\
\hline 8 & 55.0 & 4.8 & 48.8 & 37 & 2.27E-04 \\
\hline 9 & 66.7 & 6.5 & 62.0 & 30 & $1.59 \mathrm{E}-04$ \\
\hline \multicolumn{6}{|c|}{ (a) } \\
\hline \multicolumn{6}{|c|}{ NNC } \\
\hline SA & $\begin{array}{l}\text { Max Error } \\
(\%)\end{array}$ & $\begin{array}{c}\text { Performance } \\
\text { All Data } \\
(\%)\end{array}$ & $\begin{array}{c}\text { Errors > 3\% } \\
(\%)\end{array}$ & $\begin{array}{l}\text { Total Hidden } \\
\text { Nodes }\end{array}$ & $\begin{array}{c}\text { Running Time / } \\
\text { Data Point } \\
\text { (s) }\end{array}$ \\
\hline 1 & - & - & - & - & - \\
\hline 2 & _- & _ & - & ـ & - \\
\hline 3 & - & - & - & - & - \\
\hline 4 & - & - & - & - & - \\
\hline 5 & - & - & - & - & - \\
\hline 6 & - & - & - & - & - \\
\hline 7 & 9.2 & 0.3 & 4.5 & 29 & 1.79E-04 \\
\hline 8 & 54.3 & 4.8 & 48.4 & 37 & $2.40 \mathrm{E}-04$ \\
\hline 9 & 49.7 & 5.2 & 53.0 & 30 & $1.67 \mathrm{E}-04$ \\
\hline
\end{tabular}

(b)

\subsection{Proposed ANN-Based Model}

The proposed model is the one, among the best ones from all parametric SAs, exhibiting the lowest maximum error. Since in this work, several SAs yielded approximately null errors, the ANN having the least number of hidden nodes and the lowest running time per data point (SA 5) was adopted (the maximum error and performance values are of orders $10^{-11}$ and $10^{-12}$, 
D: hal-02074675

(C) 2018 by Abambres M, Lantsoght E (CC BY 4.0)

respectively). That model is characterized by the ANN feature methods $\{1,2,1,4,5,1,3,1,1,1$, 3, 2, 3, 1, 3$\}$ in Tabs. 2-4. To allow implementation of this model by any user, all variables/equations required for (i) data preprocessing, (ii) ANN simulation, and (iii) data postprocessing, are presented in $\S 3.7 .1-3.7 .3$. The proposed model is a single MLPN with 3 layers and a distribution of nodes/layer of 10-37-1. Concerning connectivity, the network is partiallyconnected, and the hidden and output transfer functions are all Hyperbolic Tangent and Logistic, respectively. The network was trained using the Levenberg-Marquardt algorithm (2565 epochs). After design, the average network computing time of a single example (including data pre/postprocessing) is $1.77 \mathrm{E}-04 \mathrm{~s}$. Fig. 4 depicts a simplified scheme of some of the network key features. Lastly, all relevant performance results of the proposed ANN are illustrated in $§ 3.7 .4$. The obtained ANN solution for every data point can be found in Developer (2018a).

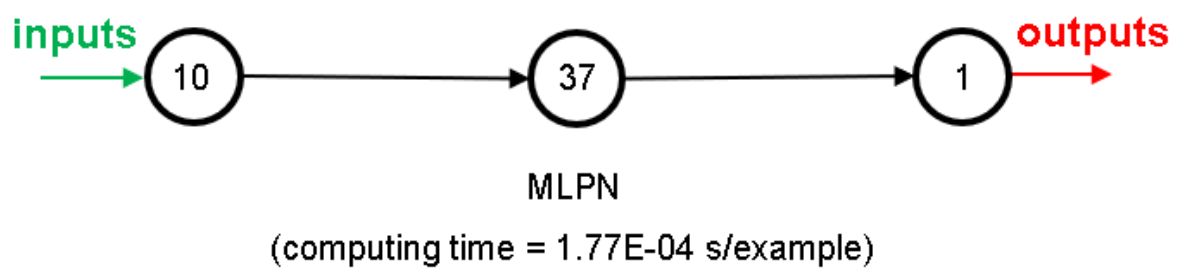

Fig. 4 Proposed 10-37-1 partially-connected MLPN - simplified scheme.

It is worth recalling that, in this manuscript, whenever a vector is added to a matrix, it means the former is to be added to all columns of the latter (valid in MATLAB). 
D: hal-02074675

(C) 2018 by Abambres M, Lantsoght E (CC BY 4.0)

\subsubsection{Input Data Preprocessing}

For future use of the proposed ANN-based model to simulate new data $Y_{1, \operatorname{sim}}\left(11 \mathrm{x} P_{\text {sim }}\right.$ matrix), concerning $P_{\text {sim }}$ patterns, the same data preprocessing (if any) performed before training must be applied to the input dataset. That preprocessing is defined by the methods used for ANN features 2, 3 and 5 (respectively 2, 1 and 5 - see Tab. 2). Next, the necessary preprocessing to be applied to $Y_{1, \text { sim }}$, concerning features 2,3 and 5 , is fully described.

\section{Dimensional Analysis}

Since dimensional analysis (d.a.) was not carried out, one has

$$
\left\{Y_{1, \text { sim }}\right\}_{\text {d.a. }}^{\text {after }}=Y_{1, \text { sim }}
$$

\section{Dimensionality Reduction}

After dimensionality reduction $(d . r$.$) , the new input dataset \left\{Y_{1, \text { sim }}\right\}_{\text {d.r. }}^{\text {after }}$ is defined as function of the previously determined $\left\{Y_{1, \text { sim }}\right\}_{\text {d.a. }}^{\text {after }}=Y_{1, \text { sim }}$, reading

$$
\begin{aligned}
& \left\{Y_{1, \text { sim }}\right\}_{\text {d.r. }}^{\text {after }}=Y_{1, \text { sim }} \\
& \left\{Y_{1, \text { sim }}\right\}_{\text {d.r. }}^{\text {after }}(6,:)=[]
\end{aligned}
$$

where the second equation removes the $6^{\text {th }}$ row from $\left\{Y_{1, \text { sim }}\right\}_{d . r .}^{\text {after }}$, after the latter has been defined in the first equation. Based on eqs. (2)-(3), Tabs. 1-2, and the 287 test results considered in this 
D: hal-02074675

(C) 2018 by Abambres M, Lantsoght E (CC BY 4.0)

study, one can say that the effective depth of the slab is a useless variable for the accurate prediction of shear capacity. It was concluded during ANN simulations (preprocessing) that the effective depth is highly and linearly correlated with some of the remaining input variables.

\section{Input Normalization}

After input normalization, the new input dataset $\left\{Y_{1, \text { sim }}\right\}_{n}^{\text {after }}$ is defined as function of the previously determined $\left\{Y_{1, \text { sim }}\right\}_{d . r}^{\text {after }}$, and they have the same size, reading

$$
\begin{gathered}
\left\{Y_{1, \text { sim }}\right\}_{n}^{\text {after }}=\left(\left\{Y_{1, \text { sim }}\right\}_{d . r}^{\text {after }}-\operatorname{INP}(:, 1)\right) . / \operatorname{INP}(:, 2) \\
\operatorname{INP}=\left[\begin{array}{cc}
1.86738675958188 & 1.75441900815846 \\
0.256292682926829 & 0.139298384453331 \\
37.6049268292683 & 15.4296708553494 \\
0.0117466550522648 & 0.00502496069944280 \\
0.00317436153310105 & 0.00313405738707657 \\
0.747257839721253 & 0.672593729449374 \\
0.409189895470383 & 0.355659673580697 \\
2.49434083623694 & 1.56947133251911 \\
3.09112818815331 & 1.68344744643481 \\
2.37830191637631 & 1.27920413483700
\end{array}\right]
\end{gathered}
$$

where one recalls that operator './' divides row $i$ in the numerator by $\operatorname{INP}(i, 2)$. 
D: hal-02074675

(C) 2018 by Abambres M, Lantsoght E (CC BY 4.0)

\subsubsection{ANN-Based Analytical Model}

Once the preprocessed input dataset $\left\{Y_{1, \text { sim }}\right\}_{n}{ }^{\text {after }}\left(10 \times P_{\text {sim }}\right.$ matrix $)$ is determined, the next step is to present it to the proposed ANN to obtain the predicted output dataset $\left\{Y_{3, s i m}\right\}_{n}^{\text {after }}\left(1 \times P_{\text {sim }}\right.$ vector), which will be given in the same preprocessed format of the target dataset used in learning. In order to convert the predicted outputs to their 'original format' (i.e., without any transformation due to normalization or dimensional analysis - the only transformation visible will be the (eventual) qualitative variables written in their numeric representation), some post-processing is needed, as described in detail in §3.7.3. Next, the mathematical representation of the proposed ANN is given, so that any user can implement it to determine $\left\{Y_{3, s i m}\right\}_{n}^{\text {after }}$, thus eliminating all rumors that ANNs are 'black boxes'.

$$
\begin{aligned}
& Y_{2}=\varphi_{2}\left(W_{1-2}^{T}\left\{Y_{1, \text { sim }}\right\}_{n}^{\text {after }}+b_{2}\right) \\
& \left\{Y_{3, \text { sim }}\right\}_{n}^{\text {after }}=\varphi_{3}\left(W_{2-3}^{T} Y_{2}+b_{3}\right)
\end{aligned}
$$

where

$$
\begin{aligned}
& \varphi_{2}=\varphi_{2}(s)=\frac{e^{s}-e^{-s}}{e^{s}+e^{-s}} \\
& \varphi_{3}=\varphi_{3}(s)=\frac{1}{1+e^{-s}}
\end{aligned}
$$


D: hal-02074675

(C) 2018 by Abambres M, Lantsoght E (CC BY 4.0)

Because of their length, arrays $W_{j-s}$ and $b_{s}$ are stored online (Developer 2018b), which also eases the model's implementation by any interested reader.

\subsubsection{Output Data Post-processing}

In order to transform the output dataset obtained by the proposed ANN, $\left\{Y_{3, s i m}\right\}_{n}^{\text {after }}\left(1 \times P_{s i m}\right.$ vector), to its original format $\left(Y_{3, \text { sim }}\right)$, i.e. without the effects of output normalization taken in target dataset preprocessing prior training, the post-processing described next must be performed.

Non-normalized (just after dimensional analysis) and original formats

Once $\left\{Y_{3, s i m}\right\}_{n}{ }^{\text {affer }}$ is obtained, eq. (7) transforms the vector to its non-normalized format $\left\{Y_{3, \text { sim }}\right\}_{\text {d.a. }}^{\text {after }}$, which equals the original format $Y_{3, \text { sim }}$ because no dimensional analysis was performed,

$$
Y_{3, \text { sim }}=\left\{Y_{3, \text { sim }}\right\}_{\text {d.a. }}^{\text {after }}=\left(\left\{Y_{3, \text { sim }}\right\}_{n}^{\text {affer }}-0.25\right) \times 4816.5652+35.225
$$

\subsubsection{Performance Results}

Finally, the results of the proposed ANN for the 287 datapoints, in terms of performance variables defined in $\S 3.4$, are presented in this section in the form of several graphs: (i) a regression plot (Fig. 5), where network target and output data are plotted, for each data point, as $x$ - and $y$ coordinates respectively - a measure of linear correlation is given by the Pearson Correlation 
ID: hal-02074675

(C) 2018 by Abambres M, Lantsoght E (CC BY 4.0)

Coefficient $(R)$; (ii) a performance plot (Fig. 6), where performance (average error) values are displayed for several learning datasets; and (iii) an error plot (Fig. 7), where values concern all data (iii 1 ) maximum error and (iii 2$) \%$ of errors greater than $3 \%$. It's worth highlighting that all graphical results just mentioned are based on effective target and output values, i.e. computed in their original format (free of any transformations due to output normalization).

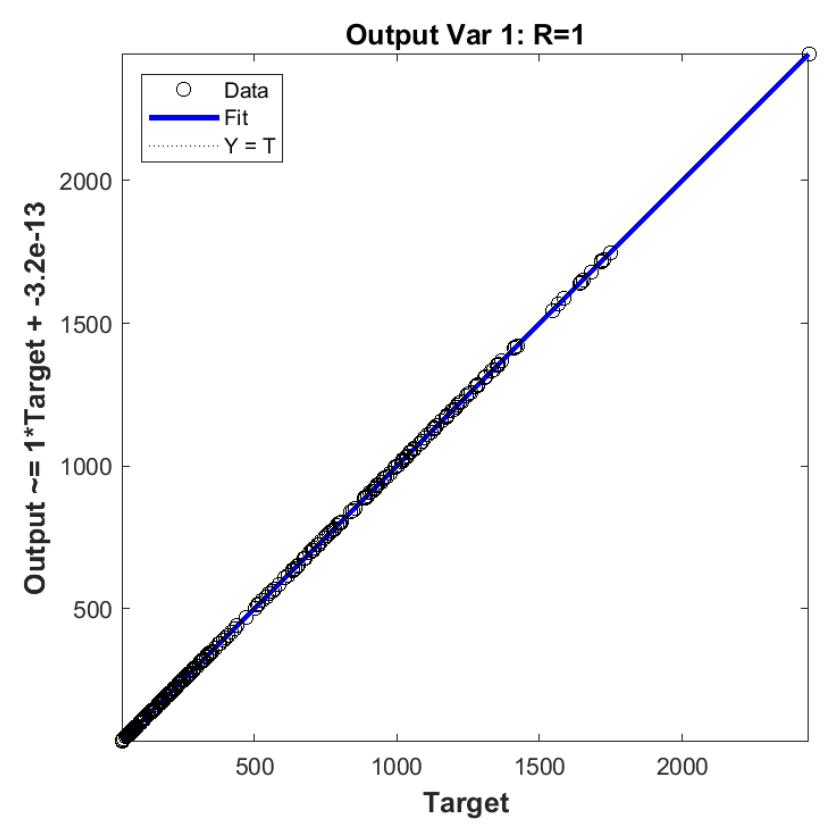

Fig. 5. Regression plot for the proposed ANN. 
D: hal-02074675

C 2018 by Abambres M, Lantsoght E (CC BY 4.0)

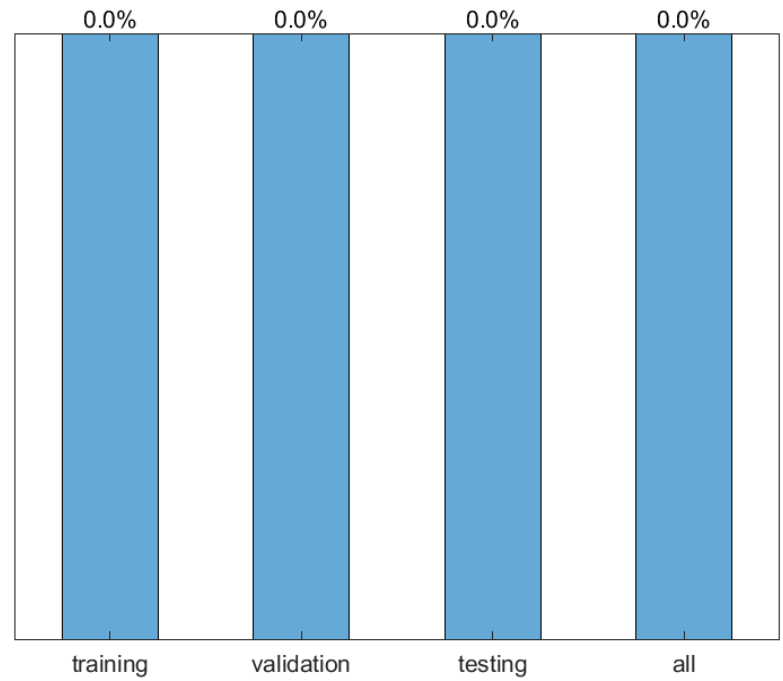

Fig. 6. Performance plot (mean errors) for the proposed ANN.

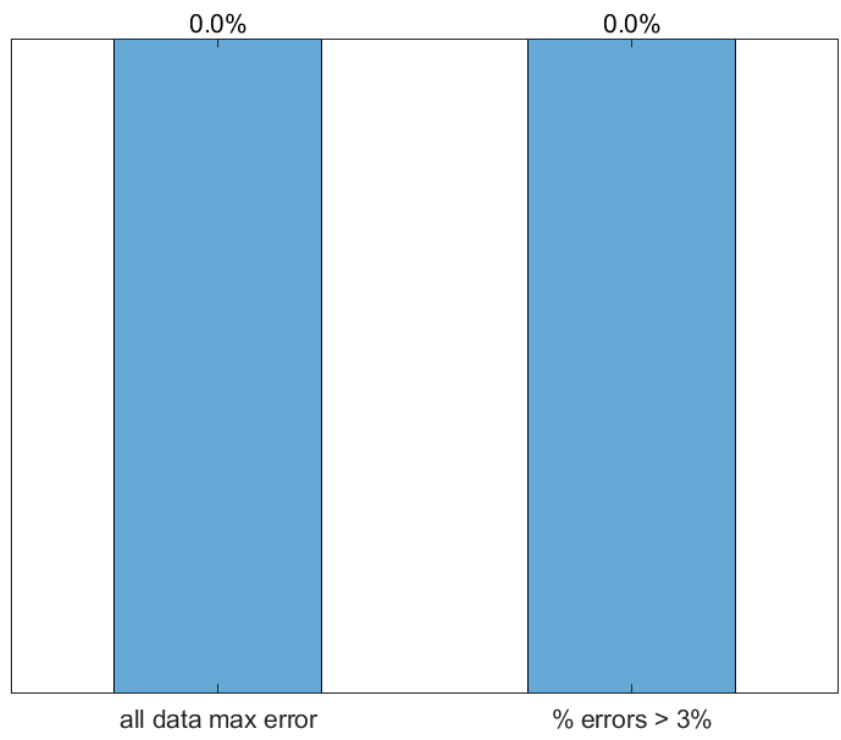

Fig. 7. Error plot for the proposed ANN. 
D: hal-02074675

(C) 2018 by Abambres M, Lantsoght E (CC BY 4.0)

\section{ANN-based vs. Existing Models}

Since the focus of this study is the assessment of reinforced concrete slab bridges in Europe, this section demonstrates the improved prediction capability of the ANN-based analytical model proposed in section 3, as compared to the shear capacity of one-way slabs predicted by the provisions of Eurocode 2 (CEN 2005). The reduction of the contribution of loads close to the support ( $a_{v} \leq 2 d_{l}$, see Fig. 1) to the sectional shear force prescribed by the Eurocode is taken into account, resulting in $V_{E, E C}$. This reduction corresponds to an increase in the shear capacity for loads close to the support as a result of direct load transfer. Since this mechanism only occurs for loads applied on top of the cross-section and close to the support, the Eurocode 2 reduces the contribution of externally applied loads close to the support. As such, this provision allows for finding the sectional shear force for a combination of loads - a situation that occurs when assessing existing reinforced concrete slab bridges. The corresponding average shear capacity according to Eurocode 2 is determined as:

$$
\begin{gathered}
V_{R, c}=0.15 k\left(100 \rho_{x} f_{c m}\right)^{1 / 3} b_{e f f} d_{l} \geq 0.035 k^{3 / 2} \sqrt{f_{c m}} b_{e f f} d_{l} \\
k=1+\sqrt{\frac{200 m m}{d_{l}}} \leq 2
\end{gathered}
$$

with (i) $k$ the size effect factor, (ii) $\rho_{x}$ the longitudinal reinforcement ratio, (iii) $f_{c m}$ the average concrete cylinder compressive strength, (iv) $b_{\text {eff }}$ the effective width for one-way shear, determined 
D: hal-02074675

(C) 2018 by Abambres M, Lantsoght E (CC BY 4.0)

with a $45^{\circ}$ horizontal load spreading from the loading plate back edge to the face of the support, and (v) $d_{l}$ the effective depth to the longitudinal reinforcement. $C_{R, c}=0.15$ is used to find average values (Regan 1987). The average value of the ratio $V_{E, E C} / V_{R, c}$ (with $V_{E, E C}$ the sectional shear force taking into account the reduction of the contribution of loads close to the support, and $V_{R, c}$ according to Eq. 8) for the 287 experimental results is 1.59 , with a standard deviation of 0.79 and a coefficient of variation of $49 \%$. For comparison, the average value of $V_{\text {test }} / V_{A N N}$ (with $V_{\text {test }}$ the sectional shear force at failure in each experiment, and $V_{A N N}$ the ANN-based shear capacity) is 1.00 , with a standard deviation of $5 \times 10^{-14}$ and a coefficient of variation of $0.0 \%$. The major improvement of the ANN as compared to the Eurocode is also shown in Fig. 8, where the $x$-axis shows the predicted shear capacity $V_{\text {model }}\left(V_{A N N}\right.$ or $\left.V_{R, c}\right)$ and the $y$-axis shows the experimental result $V_{\text {exp }}$, which is $V_{E, E C}$ for comparison to the Eurocode shear capacity and $V_{\text {test }}$ for comparison to the ANN-predicted shear capacity. Fig. 8 shows the results for the 287 datapoints used in this study. 
D: hal-02074675

(C) 2018 by Abambres M, Lantsoght E (CC BY 4.0)

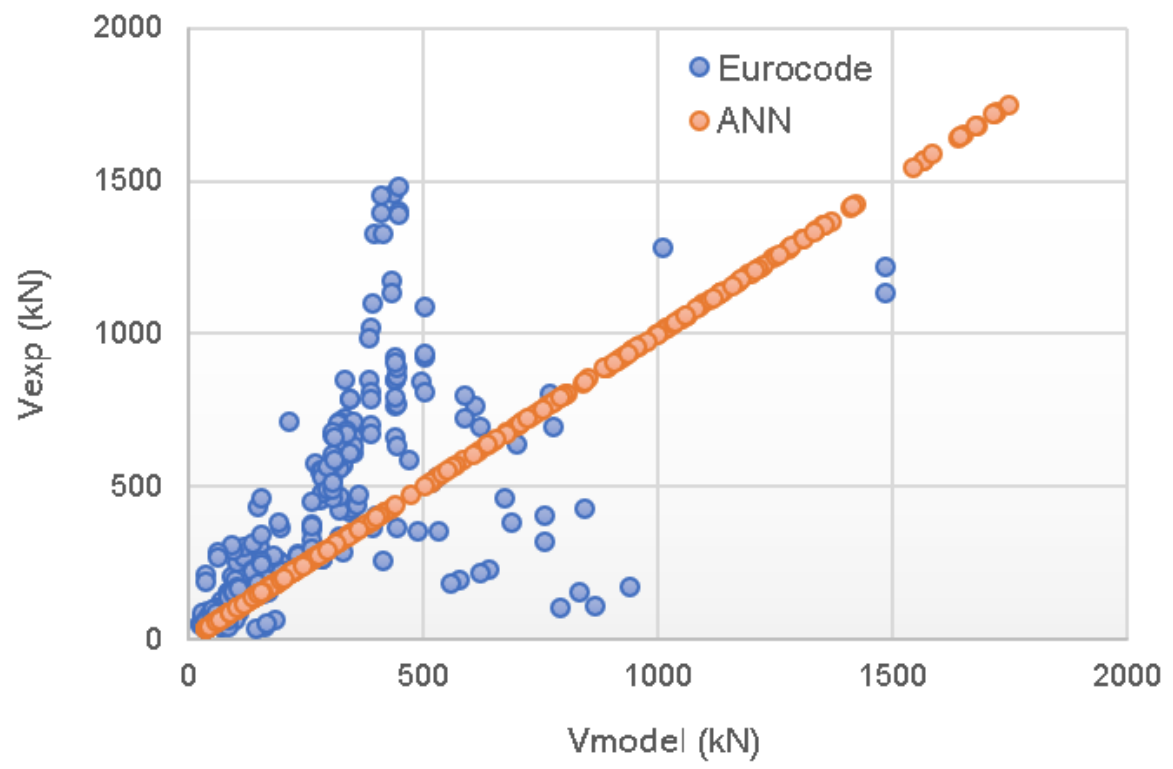

Fig. 8. Comparison between tested and predicted shear capacities: Eurocode 2 vs. proposed ANN.

\section{Discussion}

The results in Fig. 8 show the major improvement, for the 287-point dataset used, of the proposed ANN-based model as compared to currently used Eurocode 2 expressions for the shear capacity of reinforced concrete slabs in one-way shear. One critical observation should be made here: the ANN predictions are only valid within the input variable ranges of the employed 287point dataset (Developer 2018a). The number of experiments is rather limited, since slab shear tests are expensive to carry out. The user should keep this restriction in mind when predicting the shear capacity with the proposed ANN. The dataset covers a large number of variables that 
D: hal-02074675

(C) 2018 by Abambres M, Lantsoght E (CC BY 4.0)

influence the shear assessment of reinforced concrete, but all tested slabs are rectangular. For skewed slabs, shear stress concentrations will result in the obtuse angle (Cope and Clark 1984, Cope and Rao 1984, Cope 1985), making the skew angle an important factor for the shear assessment. Besides the Liverpool experiments on skewed slabs (Cope et al. 1983), which did not result in shear failures of the slabs, the authors are not aware of experiments on skewed slabs under concentrated loads failing in one-way shear. To extend this novel ANN-based design approach to new scenarios, experiments on skewed slabs failing in one-way shear should be carried out, and the skew angle should then be included as input variable for ANN design.

To use the developed ANN formulation for the assessment of existing reinforced concrete oneway slab bridges, the following procedure is proposed:

1. Make a linear finite element model (LFEM) of the bridge under consideration.

2. Apply the superimposed dead load and live load model on the LFEM.

3. Make the factored load combination according to the governing code.

4. Find the governing sectional shear force $v_{u}$ based on a distribution of the peak shear stress over $4 d_{l}$ (Lantsoght et al. 2017a) and find the governing sectional moment $m_{E}$ (including the effect of the twisting moments (Wood 1968)) based on a distribution of the peak sectional moment over $2 d_{l}$. 
D: hal-02074675

(C) 2018 by Abambres M, Lantsoght E (CC BY 4.0)

5. Determine the shear capacity with the proposed ANN $\left(V_{A N N}\right)$, taking as input the characteristic material properties (where possible updated with measured values) and the value of $M_{E} /\left(V_{E} d_{l}\right)$ where this ratio is maximum. Divide $V_{A N N}$ by $4 d_{l}$ to find $v_{A N N}$.

6. Determine the bending moment capacity $m_{R}$ based on the flexural theory of concrete elements.

7. Determine the Unity Check for shear: $U C_{v}=v_{u} / v_{A N N}$. If $U C_{v} \leq 1$, the requirements for shear are fulfilled.

8. Determine the Unity Check for bending moment: $U C_{m}=m_{E} / m_{R}$. If $U C_{m} \leq 1$, the requirements for bending moment are fulfilled.

9. If $U C_{v}>U C_{m}$ the bridge can be considered as shear-critical: shear failure is expected to occur before flexural failure.

When either $U C_{v}$ or $U C_{m}$ is found to be larger than 1, more refined methods, such as nonlinear finite element analysis or proof load testing, may be necessary for a sharper assessment of the bridge under consideration. The proposed method is fast, cheap, and computationally efficient, and as such it is especially suitable for cases where a large number of bridges need to be assessed.

\section{Final Remarks}

This paper shows how artificial neural networks can be used to predict the shear capacity of one-way slabs under concentrated loads. For this purpose, a database with 287 experimental results 
D: hal-02074675

(C) 2018 by Abambres M, Lantsoght E (CC BY 4.0)

was compiled. From this dataset, 10 governing parameters were identified as input variables and the sectional shear force at failure was considered the output variable. The proposed ANN-based analytical model yielded maximum and mean relative errors of $0.0 \%$ and $0.0 \%$ for those 287 points, respectively. Moreover, it was illustrated to clearly outperform (mean $\left.V_{t e s t} / V_{A N N}=1.00\right)$ the Eurocode 2 provisions (mean $V_{E, E C} / V_{R, c}=1.59$ ) for that dataset. Lastly, a step-by-step methodology for the assessment of existing reinforced concrete one-way slab bridges, based on the use of the developed ANN-based formula, was proposed.

The study carried out has not yet allowed a full description of the mechanics underlying the behaviour of one-way reinforced concrete slabs, but parametric studies by means of accurate and robust ANN-based models make it possible to evaluate and improve existing mechanical models.

\section{Conflicts of Interest}

None to be declared.

\section{Author Contributions}

Section 3: Abambres M.

Sections 1, 2, 4 and 5: Lantsoght E.

All other sections have equal contributions from both authors.

\section{Funding}

This research was funded by Universidad San Francisco de Quito under the program of Collaboration Grants 2019. The APC was funded by Delft University of Technology. 
D: hal-02074675

(C) 2018 by Abambres M, Lantsoght E (CC BY 4.0)

\section{Acknowledgments}

The authors are grateful for the financial support received from Universidad San Francisco de Quito through the 2019 'Collaboration Grants' program.

\section{References}

Abambres M, Marcy M, Doz G (2018). Potential of Neural Networks for Structural Damage Localization, hal-02074844

Adhikary BB, Mutsuyoshi H (2006). Prediction of shear strength of steel fiber RC beams using neural networks. Construction and Building Materials, 20(9), 801-811, doi: https://doi.org/10.1016/j.conbuildmat.2005.01.047.

Al-Musawi AA (2018). Determination of shear strength of steel fiber RC beams: application of dataintelligence models. Frontiers of Structural and Civil Engineering, 1-7, doi: https://doi.org/10.1007/s11709-018-0504-4.

Aster H, Koch R (1974). Schubtragfahigkeit dicker Stahlbetonplatten. Beton- und Stahlbetonbau, 69(11), 266-270.

Aymerich F, Serra M (1998). Prediction of fatigue strength of composite laminates by means of neural networks. Key Engineering Materials, 144(September), 231-240.

Belletti B, Damoni c, Hendriks MAN, Den Uij1 JA (2013). Nonlinear finite element analyses of reinforced concrete slabs: comparison of safety formats, in: VIII International Conference on Fracture Mecahnics of concrete and Concrete Structures, FraMCoS-8. (eds.) J.G.M. Van Mier, G Ruiz, C Andrade, RC Yu $\&$ XX Zhang).

Blomfors M, Engen M, Plos M (2016). Evaluation of safety formats for non-linear finite element analyses of statically indeterminate concrete structures subjected to different load paths. Structural Concrete, 17(1), 44-51, doi: https://doi.org/10.1002/suco.201500059.

CEN (2003). Eurocode 1: Actions on structures - Part 2: Traffic loads on bridges, NEN-EN 1991-2:2003. Brussels, Belgium: Comité Européen de Normalisation.

CEN (2005). Eurocode 2: Design of Concrete Structures - Part 1-1 General Rules and Rules for Buildings. NEN-EN 1992-1-1:2005. Brussels, Belgium: Comité Européen de Normalisation.

Coin A, Thonier H (2007). Essais sur le cisaillement des dalles en beton arme. Annales du batiment et des travaux publics, 7-16.

Collins MP, Kuchma D (1999). How safe are our large, lightly reinforced concrete beams, slabs, and footings? ACI Structural Journal, 96(4), 482-490.

Cope RJ (1985). Flexural Shear Failure of Reinforced-Concrete Slab Bridges. Proceedings of the Institution of Civil Engineers Part 2-Research and Theory, 79(SEP), 559-583.

Abambres M, Lantsoght E (2018). Neural network-based formula for shear capacity prediction of 
ID: hal-02074675

(C) 2018 by Abambres M, Lantsoght E (CC BY 4.0)

Cope RJ, Clark LA (1984). Concrete slabs: analysis and design. London: Elsevier Applied Science.

Cope RJ, Rao PV (1984). Shear Forces in Edge Zones of Concrete Slabs. Structural Engineer, 62(3), 87-92.

Cope RJ, Rao PV, Edwards KR (1983). Shear in skew reinforced concrete slab bridges - analytical and experimental studies - A report to the Department of Transport. Liverpool, UK: University of Liverpool.

Cullington DW, Daly AF, Hill ME (1996). Assessment of reinforced concrete bridges: Collapse tests on Thurloxton underpass. Bridge Management, 3, 667-674.

Developer (2018a). dataset + results, downloadable

Developer (2018b). W and b arrays, downloadable

Diaz de Cossio R, Moe J, Gould PL, Meason JG (1962). Shear and diagonal tension - Discussion. ACI Journal Proceedings, 59(11), 1323-1339.

Ekeberg PK, Sjursen A, Thorenfeldt E (1982). Load-carrying capacity of continuous concrete slabs with concentrated loads (in Norwegian). Nordisk betong, 4(2), 153-156.

Falbr J (2011). Shear redistribution in solid concrete slabs. MSc, Delft University of Technology.

Fang IK, Tsui CKT, Burns NH, Klingner RE (1990). Load Capacity of Isotropically Reinforced, Cast-inPlace and Precast Panel Bridge Decks. PCI Journal, 35(4), 104-113.

Flood I (2008). Towards the next generation of artificial neural networks for civil engineering. Advanced Engineering Informatics, 22(1), 4-14, doi: https://doi.org/10.1016/j.aei.2007.07.001.

Flood I, Kartam N (1994). Neural Networks in Civil Engineering. I: Principles and Understanding. Journal of Computing in Civil Engineering, 8(2), 131-148, doi: https://doi.org/10.1061/(ASCE)08873801(1994)8:2(131).

Frissen CM (2018). User manual for ARP (Automatic Calculation Procedure Slabs) (in Dutch). Delft, the Netherlands: DIANA FEA.

Furuuchi H, Takahashi Y, Ueda T, Kakuta Y (1998). Effective width for shear failure of RC deep slabs. Transactions of the Japan concrete institute, 20, 209-216.

Gandomi AH, Yun GJ, Alavi AH (2013). An evolutionary approach for modeling of shear strength of RC deep beams. Materials and Structures, 46(12), 2109-2119, doi: https://doi.org/10.1617/s11527-013-0039-z.

Gholizadeh S, Pirmoz A, Attarnejad R (2011). Assessment of load carrying capacity of castellated steel beams by neural networks. Journal of Constructional Steel Research, 67(5), 770-779. doi: https://doi.org/10.1016/j.jcsr.2011.01.001

Graf O (1933). Versuche über die Widerstandsfähigkeit von Eisenbetonplatten unter konzentrierter Last nahe einem Auflager Deutscher Ausschuss für Eisenbeton 73, 10-16.

Haykin SS (2009). Neural networks and learning machines. New York: Prentice Hall/Pearson.

Abambres M, Lantsoght E (2018). Neural network-based formula for shear capacity prediction of 
ID: hal-02074675

(C) 2018 by Abambres M, Lantsoght E (CC BY 4.0)

Heger FJ, McGrath TJ (1980). Design method for reinforced concrete pipe and box sections, (ed.) T.C.o.t.A.C.P. Association (Camebridge, Massachusetts; San Francisco, California: Simpson Gumpertz \& Heger Inc.).

Hern A (2016). Google says machine learning is the future. So I tried it myself [Online]. Available: https://www.theguardian.com/technology/2016/jun/28/google-says-machine-learning-is-the-future-soi-tried-it-myself [Accessed Dec 27, 2018].

Hertzmann A, Fleet D (2012). Machine Learning and Data Mining, Lecture Notes CSC 411/D11. Canada: Computer Science Department, University of Toronto.

Hossain KMA, Gladson LR, Anwar MS (2016). Modeling shear strength of medium- to ultra-high-strength steel fiber-reinforced concrete beams using artificial neural network. Neural Computing and Applications, 28(1), 1119-1130, doi: http://doi.org/10.1007/s00521-016-2417-2.

Jaeger T, Marti P (2009). Reinforced Concrete Slab Shear Prediction Competition: Experiments. ACI Structural Journal, 106(3), 300-308.

Jäger T (2005). Versuche zum Querkraftwiderstand und zum Verformungsvermogen von Stahlbetonplatten, Zurich: ETH Zurich.

Jäger T (2007). Querkraftwiderstand und Verformungsvermogen vond Stahlbetonplatten. PhD thesis, ETH Zurich.

Jung S, Kim KS (2008). Knowledge-based prediction of shear strength of concrete beams without shear reinforcement. Engineering Structures, 30(6), 1515-1525.

Kani GNJ (1964). The Riddle of Shear Failure and Its Solution. ACI Journal Proceedings, 61(4), 441-467.

Kani MW, Huggins MW, Wittkopp RR (1979). Kani on Shear in Reinforced Concrete. Toronto: Univ of Toronto, Dept of Civil Engineering.

Kara IF (2013). Empirical modeling of shear strength of steel fiber reinforced concrete beams by gene expression programming. Neural Computing and Applications, 23(3), 823-834, doi: http://doi.org/10.1007/s00521-012-0999-x.

Lantsoght EOL (2013). Shear in Reinforced Concrete Slabs under Concentrated Loads Close to Supports. Delft University of Technology, PhD Thesis.

Lantsoght EOL, de Boer A, van der Veen C (2017a). Distribution of peak shear stress in finite element models of reinforced concrete slabs. Engineering Structures, 148(October), 571-583, doi: https://doi.org/10.1016/j.engstruct.2017.07.005.

Lantsoght EOL, van der Veen C, de Boer A (2017b). Extended Strip Model for slabs subjected to load combinations. Engineering Structures, 145, 60-69.

Lantsoght EOL, van der Veen C, de Boer A, Alexander SDB (2017c). Extended Strip Model for Slabs under Concentrated Loads. ACI Structural Journal, 114(2), 565-574.

Lantsoght EOL, van der Veen C, de Boer A, Walraven J (2015a). Transverse Load Redistribution and Effective Shear Width in Reinforced Concrete Slabs. Heron, 60(3), 145-180. 
ID: hal-02074675

(C) 2018 by Abambres M, Lantsoght E (CC BY 4.0)

Lantsoght EOL, van der Veen C, de Boer A, Walraven JC (2013a). Recommendations for the Shear Assessment of Reinforced Concrete Slab Bridges from Experiments Structural Engineering International, 23(4), 418-426.

Lantsoght EOL, van der Veen C, Walraven JC (2013b). Shear in One-way Slabs under a Concentrated Load close to the support. ACI Structural Journal, 110(2), 275-284.

Lantsoght EOL, van der Veen C, Walraven JC, de Boer A (2015b). Database of wide concrete members failing in shear. Magazine of Concrete Research, 67(1), 33-52.

Lantsoght EOL, van der Veen C, Walraven JC, de Boer A (2015c). Transition from one-way to two-way shear in slabs under concentrated loads. Magazine of Concrete Research, 67(17), 909-922.

Leonhardt F, Walther R (1962a). Beitrage zur Behandlung der Schubprobleme in Stahlbetonbau - 2. Fortsetzung des Kapitels II. Versuchsberichte. Beton- und Stahlbetonbau, 57(3), 54-64.

Leonhardt F, Walther R (1962b). The Stuttgart shear tests, 1961; contributions to the treatment of the problems of shear in reinforced concrete construction. London: Cement and Concrete Association.

McCulloch WS, Pitts W (1943). A logical calculus of the ideas immanent in nervous activity. The bulletin of mathematical biophysics, 5(4), 115-133, doi: http://doi.org/10.1007/bf02478259.

Miller RA, Aktan AE, Shahrooz BM (1994). Destructive testing of decommisisioned concrete slab bridge. Journal of Structural Engineering, 120(7), 2176-2198.

Mohammadyan-Yasouj SE, Marsono AK, Abdullah R, Moghadasi M (2015). Wide Beam Shear Behavior with Diverse Types of Reinforcement. ACI Structural Journal, 112(2), 199-208.

Mukherjee A, Deshpande JM, Anmala J (1996). Prediction of Buckling Load of Columns Using Artificial Neural Networks. Journal of Structural Engineering, 122(11), 1385-1387, doi: http://doi.org/10.1061/(ASCE)0733-9445(1996)122:11(1385).

Naik U, Kute S (2013). Span-to-depth ratio effect on shear strength of steel fiber-reinforced high-strength concrete deep beams using ANN model. International Journal of Advanced Structural Engineering, 5(1), 29, doi: http://doi.org/10.1186/2008-6695-5-29.

Naser MZ (2018). Deriving temperature-dependent material models for structural steel through artificial intelligence. Construction and Building Materials, 191, 56-68, doi: https://doi.org/10.1016/j.conbuildmat.2018.09.186.

Olonisakin AA, Alexander SDB (1999). Mechanism of shear transfer in a reinforced concrete beam. Canadian journal of civil engineering, 26(6), 810-817.

Prieto A, Prieto B, Ortigosa EM, Ros E, Pelayo F, Ortega J, et al. (2016). Neural networks: An overview of early research, current frameworks and new challenges. Neurocomputing, 214, 242-268, doi: https://doi.org/10.1016/j.neucom.2016.06.014.

$\mathrm{Pu}$ Y, Mesbahi E (2006). Application of artificial neural networks to evaluation of ultimate strength of steel panels. Engineering Structures, 28(8), 1190-1196, doi: https://doi.org/10.1016/j.engstruct.2005.12.009.

Abambres M, Lantsoght E (2018). Neural network-based formula for shear capacity prediction of 
ID: hal-02074675

(C) 2018 by Abambres M, Lantsoght E (CC BY 4.0)

Rajagopalan KS, Ferguson PM (1968). Exploratory shear tests emphasizing percentage of longitudinal steel. ACI Journal Proceedings, 65(8), 634-638.

Regan PE (1982). Shear Resistance of Concrete Slabs at Concentrated Loads close to Supports, London, United Kingdom: Polytechnic of Central London.

Regan PE (1987). Shear resistance of members without shear reinforcement; proposal for CEB Model Code MC90. London, UK: Polytechnic of Central London.

Regan PE (1993). Research on shear: a benefit to humanity or a waste of time. The structural engineer, 71(19), 337-347.

Regan PE, Rezai-Jorabi H (1988). Shear Resistance of One-Way Slabs under Concentrated Loads. ACI Structural Journal, 85(2), 150-157.

Reineck K-H, Koch R, Schlaich J (1978). Shear Tests on Reinforced concrete beams with axial compression for offshore structures. Institut für Massivbau, Universität Stuttgart.

Reißen K, Hegger J (2011). Experimental Study on the Shear Capacity of Concrete Slabs, in: IABSE 2011.

Reißen K, Hegger J (2013a). Experimentelle Untersuchingen zur mitwirkenden Breite fur Querkraft von einfeldrigen Fahrbahnplatten. Beton- und Stahlbetonbau, 108(2), 96-103.

Reißen K, Hegger J (2013b). Experimentelle Untersuchungen zum Querkrafttragverhalten von auskragenden Fahrbahnplatten unter Radlasten. Beton- und Stahlbetonbau, 108(5), 315-324.

Researcher T (2018). ANN Software Validation-Report. Figshare, doi: 10.6084/m9.figshare.6962873.v1

Richart FE (1948a). Reinforced Concrete Wall and Column Footings: part 1. ACI Journal Proceedings, 45(2), 97-127.

Richart FE (1948b). Reinforced Concrete Wall and Column Footings: part 2. ACI Journal Proceedings, 45(3), 237-260.

Richart FE, Kluge RW (1939). Tests of reinforced concrete slabs subjected to concentrated loads; a report of an investigation, in: University of Illinois Engineering Experiment Station Bulletin No. 314, Urbana: University of Illinois.

Rombach G, Latte S, Steffens R (2009). Querkrafttragfahigkeit von Fahrbahnplatten ohne Querkraftbewehrung. Forschung StraBenbau under StraBenverkehrstechnik, 94, doi: http://doi.org/10.1002/best.200900029.

Rombach GA, Latte S (2008). Shear resistance of bridge decks without shear reinforcement, in: International FIB Symposium 2008. Amsterdam, The Netherlands: Fédération Internationale du Béton.

Rombach GA, Velasco RR (2005). Schnittgrößen auskragender fahrbahnplatten infolge von radlasten nach DIN-fachbericht. Beton- und Stahlbetonbau, 100(5), 376-389.

Abambres M, Lantsoght E (2018). Neural network-based formula for shear capacity prediction of 
ID: hal-02074675

(C) 2018 by Abambres M, Lantsoght E (CC BY 4.0)

Sarveghadi M, Gandomi AH, Bolandi H, Alavi AH (2015). Development of prediction models for shear strength of SFRCB using a machine learning approach. Neural Computing and Applications, doi: http://doi.org/10.1007/s00521-015-1997-6.

Schlune H (2011). Safety Evaluation of Concrete Structures with Nonlinear Analysis. Ph.D Thesis, Chalmers University.

Schlune H, Plos M, Gylltoft K (2011). Safety formats for nonlinear analysis tested on concrete beams subjected to shear forces and bending moments. Engineering Structures, 33(8), 2350-2356, doi: http://doi.org/10.1016/j.engstruct.2011.04.008.

Serna-Ros P, Fernandez-Prada MA, Miguel-Sosa P, Debb OAR (2002). Influence of stirrup distribution and support width on the shear strength of reinforced concrete wide beams. Magazine of Concrete Research, 54(3), 181-191.

Sherwood EG, Lubell AS, Bentz EC, Collins MR (2006). One-way shear strength of thick slabs and wide beams. ACI Structural Journal, 103(6), 794-802.

Shu J, Bagge N, Plos M, Johansson M, Yang Y, Zandi K (2018). Shear Capacity of a RC Bridge Deck Slab: Comparison between Multilevel Assessment and Field Test. Journal of Structural Engineering, 144(7), 04018081, doi: http://doi.org/10.1061/(ASCE)ST.1943-541X.0002076.

Talbot AN (1905). Tests of reinforced concrete beams. Urbana: University of Illinois.

Talbot AN (1906). Tests of reinforced concrete T-beams. Urbana: University of Illinois.

Talbot AN 1908. A test of three large reinforced concrete beams. Urbana: University of Illinois.

The Mathworks, Inc. (2017). Matlab R2017a, User's Guide. Natick, USA.

van der Veen C, Gijsbers FBJ (2011). Working set factors existing concrete bridges - Memo shear assessment existing bridges.

Vaz Rodrigues R (2006). Shear Strength of RC bridge deck cantilevers, in: 6th International PhD Symposium in Civil Engineering. Zurich, Switzerland: Fédération Internationale du Béton.

Vaz Rodrigues R, Muttoni A, Olivier O (2006). Large Scale Tests on Bridge Slabs Cantilevers Subjected to Traffic Loads, in: 2nd international FIB Congress. Naples, Italy: Fédération Internationale du Béton.

Venkata Rao K, Murthy PBGSN (2018). Modeling and optimization of tool vibration and surface roughness in boring of steel using RSM, ANN and SVM. Journal of Intelligent Manufacturing, 29(7), 1533-1543, doi: http://doi.org/10.1007/s10845-016-1197-y.

Walraven JC (2010). Residual shear bearing capacity of existing bridges, in: fib Bulletin 57, Shear and punching shear in RC and FRC elements, Proceedings of a workshop held on 15-16 October 2010. Salò, Lake Garda, Italy.

Abambres M, Lantsoght E (2018). Neural network-based formula for shear capacity prediction of 
D: hal-02074675

(C) 2018 by Abambres M, Lantsoght E (CC BY 4.0)

Weinstein Jordan C, Sanayei M, Brenner Brian R (2018). Bridge Damage Identification Using Artificial Neural Networks. Journal of Bridge Engineering, 23(11), 04018084. doi: http://doi.org/10.1061/(ASCE)BE.1943-5592.0001302.

Wilamowski BM, Irwin JD (2011). The industrial electronics handbook. Boca Raton, FL: CRC ; Taylor \& Francis distributor.

Wood RH (1968). The reinforcement of slabs in accordance with a pre-determined field of moments. Concrete(February), 69-76.

Yaseen ZM, Deo RC, Hilal A, Abd AM, Bueno LC, Salcedo-Sanz S, et al. (2018). Predicting compressive strength of lightweight foamed concrete using extreme learning machine model. Advances in Engineering Software, 115, 112-125, doi: https://doi.org/10.1016/j.advengsoft.2017.09.004.

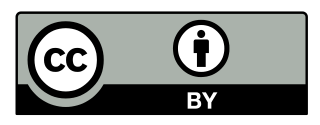

(C) 2018 by Abambres M, Lantsoght E. Open access publication under the terms and conditions of the Creative Commons Attribution 4.0 (CC BY 4.0) license (http://creativecommons.org/licenses/by/4.0) 